\author{
Мардар M.P. \\ доктор технічних наук, доцент \\ профресор кафедри маркетингу, підприємництва і торгівлі \\ Одеська національна академія харчових технологій \\ вул. Канатна, 112, м. Одеса, Україна, 65039 \\ E-mail: marina_mardar@mail.ru
}

\title{
ФОРМУВАННЯ СПОЖИВЧИХ ПЕРЕВАГ ДО ФУНКЦІОНАЛЬНИХ ПРОДУКТІВ ХАРЧУВАННЯ НА ОСНОВІ МАРКЕТИНГОВИХ ДОСЛІДЖЕНЬ
}

\begin{abstract}
Представлені результати маркетингових досліджень ставлення споживачів до функціональних продуктів харчування, визначено яким рівнем знань володіє потенційний споживач та на основі отриманих даних запропоновано шляхи формування споживчих переваг до функціональних продуктів харчування. Інформація, яка буде надходити за допомогою запропонованих дій, дозволить сформувати знання у споживача й тим самим забезпечити його усвідомлену потребу до нових продуктів, тобто мати на ринку сформовані споживчі переваги.
\end{abstract}

Ключові слова: маркетингові дослідження, споживач, функціональні продукти харчування, споживчі переваги.

Постановка проблеми та їі зв'язок з важливими науковими та практичними завданнями. Одним із найважливіших та перспективних напрямків розвитку харчової промисловості є створення безпечних та, разом з тим, повноцінних за складом і споживчими властивостями функціональних продуктів харчування (ФПХ), здатних підтримувати стан здоров'я споживачів на належному рівні, а також знижувати ризики виникнення цілої низки захворювань [1].

Незбалансованість сучасного харчування, неспроможність забезпечити організм людини необхідною кількістю незамінних поживних та біологічно активних речовин є глобальною проблемою як у розвинутих країнах, так і в країнах, що розвиваються. Організація збалансованого харчування є основним чинником формування здоров'я нації, забезпечення високого ступеня реалізації іiї розумового, трудового, творчого та репродуктивного потенціалу, що визначає економічний розвиток країни та забезпечує високий рівень соціального, культурного, економічного життя людей, їх фізичного та духовного добробуту [2].

Результати спостережень вітчизняних вчених свідчать, що понад 50\% населення України харчується неякісно. Неповноцінне за кількісним та якісним складом, а також незбалансоване за енергетичною та поживною цінністю харчування сприяє розвитку аліментарних та аліментарно-залежних захворювань [3, 4].

Для вирішення цих проблем в Україні сформовані та реалізуються загальнодержавні програми «Здорова нація», «Здоров'я - 2020: Український вимір», «Біофортифікація та функціональні продукти на основі рослинної сировини на 2012-2016 роки», які направлені на профілактику захворювань, пов'язаних 3 неправильним харчуванням.

Сучасний європейський ринок ФПХ щорічно зростає на $10 \%$, у той час як приріст традиційних продуктів становить 1,3 - 1,5\%, що трактується експертами як підвищення попиту на продукти здорового харчування. Згідно прогнозам провідних спеціаліс- тів світу в галузі харчування великого успіху досягнуть виробники, які зможуть переконати покупця, що їх функціональні продукти мають науково обгрунтований склад і високі органолептичні властивості, зручні у споживанні, а також абсолютно безпечні [5-10]. Сьогодні значна частина представників харчової індустрії стратегічно орієнтовані на виробництво функціональних продуктів або інгредієнтів для оздоровчого харчування. Але при цьому асортимент вітчизняних продуктів харчування мінімальний і потребує розширення та оптимізації. Також статистичні дані показують порівняно низький рівень споживання ФПХ в Україні, на нашу думку, це пояснюється низькою зацікавленістю споживачів у даній групі продуктів [3, 4, 11]. Це обумовлено недостатньою інформацією та відсутністю знань у споживача про оздоровчі продукти харчування. У зв'язку з цим актуальним $\epsilon$ інформаційне забезпечення споживача про ФПХ 3 метою формування споживчих переваг до даних продуктів.

Формулювання цілей дослідження. Основною метою статті було проведення маркетингових досліджень ставлення споживачів до ФПХ, визначення якім рівнем знань володіє потенційний споживач та на основі отриманих даних запропонувати шляхи формування споживчих переваг до ФПХ.

Виклад основних результатів та їх обгрунтування. Маркетингові дослідження проводили у формі тестового опитування. Обсяг вибірки - 538 осіб (доросле населення м. Одеси у віці 18 років і більше). Метод формування вибірки - квотний апріорний відбір (квотування за параметрами статі й віку), на основі демографічних даних про структуру населення в м. Одесі. Метод збору інформації - опитування населення на вулицях міста Одеси методом особистого інтерв'ю, тривалість якого становила в середньому до 10 хвилин.

Розподіл респондентів залежно від рівня освіти: 3 вищою освітою - 58,6 \%, незакінчена вища $19,6 \%$, із середньою - 21,8 \%. За родом занять у вибірку увійшли, \%: викладачі - 14,2; робітники - 13,3; 
службовці - 21,5; пенсіонери - 19,8; студенти - 14,3; підприємці - 4,4. На частку непрацюючих (безробітні, домогосподарки) припадає 5,6\%. Інший рід занять указали $6,9 \%$ опитаних.

Першочергово цікаво було з'ясувати, як споживач оцінює стан свого здоров'я. Дослідження показало, що в цілому людей, які вважають себе здоровими не так уже й багато, усього лише кожний третій (в основному молоді люди у віці 18-29 років, незалежно від статті, віку, рівня доходу, освіти). Більшість споживачів $(68,2 \%)$ вважають себе «нездоровими» людьми (у цю групу ввійшли респонденти старше 40 років незалежно від статті, рівня освіти та доходу) i серед захворювань відзначали такі як: серцевосудинні - 20,1\% опитаних, органів травлення $12,8 \%$, верхніх дихальних шляхів - 8,9\%, алергії $7,9 \%$, онкологічні - 7,4 \%, інші захворювання вказали $11,1 \%$ опитаних.

У числі пріоритетних причин виникнення захворювань респонденти відзначили несприятливу екологічну обстановку $18,6 \%$ опитаних; недостатнє (незбалансоване) харчування вказали - 28,8 \% опитаних; 9,5 \% відзначили професійні особливості; 19,2 \% - стреси; 7,4 \% - вікові зміни; 10,4\% - спадковість. Серед інших причин захворювань респонденти $(6,1 \%)$ відзначили: забруднення продуктів харчування, шкідливі звички й ін. Безперечно, можна сказати, що здоровий спосіб життя й насамперед здорове харчування $\epsilon$ найважливішими факторами впливу на здоров'я людини, більш важливими, ніж інші фактори (екологічні, соціально-економічні та ін.)

У цей же час перешкодою раціональному харчуванню є не тільки недостатня матеріальна забезпеченість значної частини населення, але й відсутність або недолік знань про те, як потрібно харчуватися, чому віддати перевагу й від чого відмовитися. Тому далі були проведені дослідження з метою виявлення яким рівнем знань володіє потенційний споживач.

Виявлений рівень інформованості населення про ФПХ, про їх властивості, про їх значення показав, що $46 \%$ респондентів оцінили свої знання як недостатні й $10 \%$ як відсутні. У свідомості споживача склалося наступне уявлення про ФПХ: продукти з незрозумілим набором властивостей i переваг стосовно традиційних продуктів харчування, мають не завжди зрозумілу інструкцію й рекомендації стосовно споживання, також багато респондентів відзначили низьку якість даних продуктів. Респондентами вказувалося на те, що властивості, які були приписані цим продуктам у рекламі, відсутні у реальності, і функціональні продукти - це спроба заплутати споживача й змусити купити звичайний продукт, 3 нібито незвичайними властивостями. Результати опитування відображають несформовані потреби у ФПХ та процес, що й уже почався, їх відторгнення через нерозуміння значення даних продуктів. Отримані результати корелюють 3 даними маркетингових досліджень, які були проведені під керівництвом проф. Маюрникової Л.А. [12]. У результаті наших досліджень виявлено, що найбільш інформованими про ФПХ були респонденти віку 18-40 років з вищою освітою переважно із сфери медицини та технологї виробництва продуктів харчування. Встановлено, що зі зниженням рівня освіти, соціального статусу опитуваних підвищується відсоток тих споживачів, які нічого не знають про здорове харчування. Отримані результати корелюють iз розробленою раніше моделлю формування споживних переваг у споживача залежно від отриманих знань [2]. Згідно 3 даною моделлю 3 підвищенням рівня знань та соціального статусу споживач орієнтується у першу чергу на продукти, які крім ціни характеризуються безпечністю і якістю. Споживач із високим рівнем знань, як правило, звертає свою увагу на продукти оздоровчого призначення, екологічно чисті продукти, він керується такими критеріями, як корисність, якість, натуральність, безпечність, і вже в останню чергу ціною, кількістю та їх співвідношенням.

У ході маркетингових досліджень виявлено, що основними мотивами придбання й споживання ФПХ були: профілактика дефіциту мінеральних речовин та вітамінів - 20,6\%; поліпшення процесу травлення - 13,4 \%; вживання збалансованого продукту за харчовою цінністю - 29,8\%; просто смачно - 3,3. Але частота придбання низька, тобто дані продукти не входять у звичайний харчовий раціон, отже, не виконують свої основні функції.

Значущими властивостями для вибору ФПХ $€$ (рис.1): інформація про товар (23\%), ціна (14\%), смакові властивості (17\%), репутація виробника (15\%), корисність (18\%). Отримані дані свідчать о необхідності формування споживчих переваг до ФПХ.

Цікаво було визначити найбільш популярні для споживача джерела інформації про ФПХ, а також, яким джерелам респонденти віддають перевагу, тобто більше довіряють (рис. 2).

Дані рис. 2 показують невідповідність між найпоширенішими джерелами інформації та довірою, яку виражають до них респонденти. Так, найбільш популярними джерелами інформації є друзі та знайомі (їх назвали 20,9\%), газети й журнали (16,8\%), у той час як довіряють їм лише $10,9 \%$ і 7,6 \% відповідно. Це протиріччя можна пояснити тим, що як перший, так і другий канали інформації є джерелами великої кількості найрізноманітніших відомостей, найчастіше неправильних, неточних або суперечливих, тому ступінь довіри до них невеликий. Низький ступінь довіри мають такі джерела, як реклама на телебаченні, інтернет, продавці, що можна пояснити зацікавленістю цих інформаційних каналів у продажі свого товару. Найбільшу довіру в опитуваних викликають лікарі (26,2 \%), викладачі $(21,4 \%)$, спеціальна література (23,2 \%). При цьому необхідно відзначити, що від даних джерел отримують інформацію тільки 9,8 \%, 14,8 \% і 9,7 \% споживачів, відповідно. Ця невідповідність вказує на те, що дані комунікативні канали мають великий резерв і становлять особливий інтерес у силу високого рівня довіри до них. Отже, необхідно більше залучати лікарів, викладачів, науково-дослідних працівників до просвітницької роботи серед населення в питаннях правильного харчування. Цікаво, що досить високий рівень комп'ютеризації не сприяє одержанню достовірної інформації про прави- 
льне харчування із цього джерела. Так, інтернет відзначили всього $3 \%$ респондентів. Результати дослі- джень показали, що населення недостатньо інформоване про принципи здорового харчування, про ФПХ.

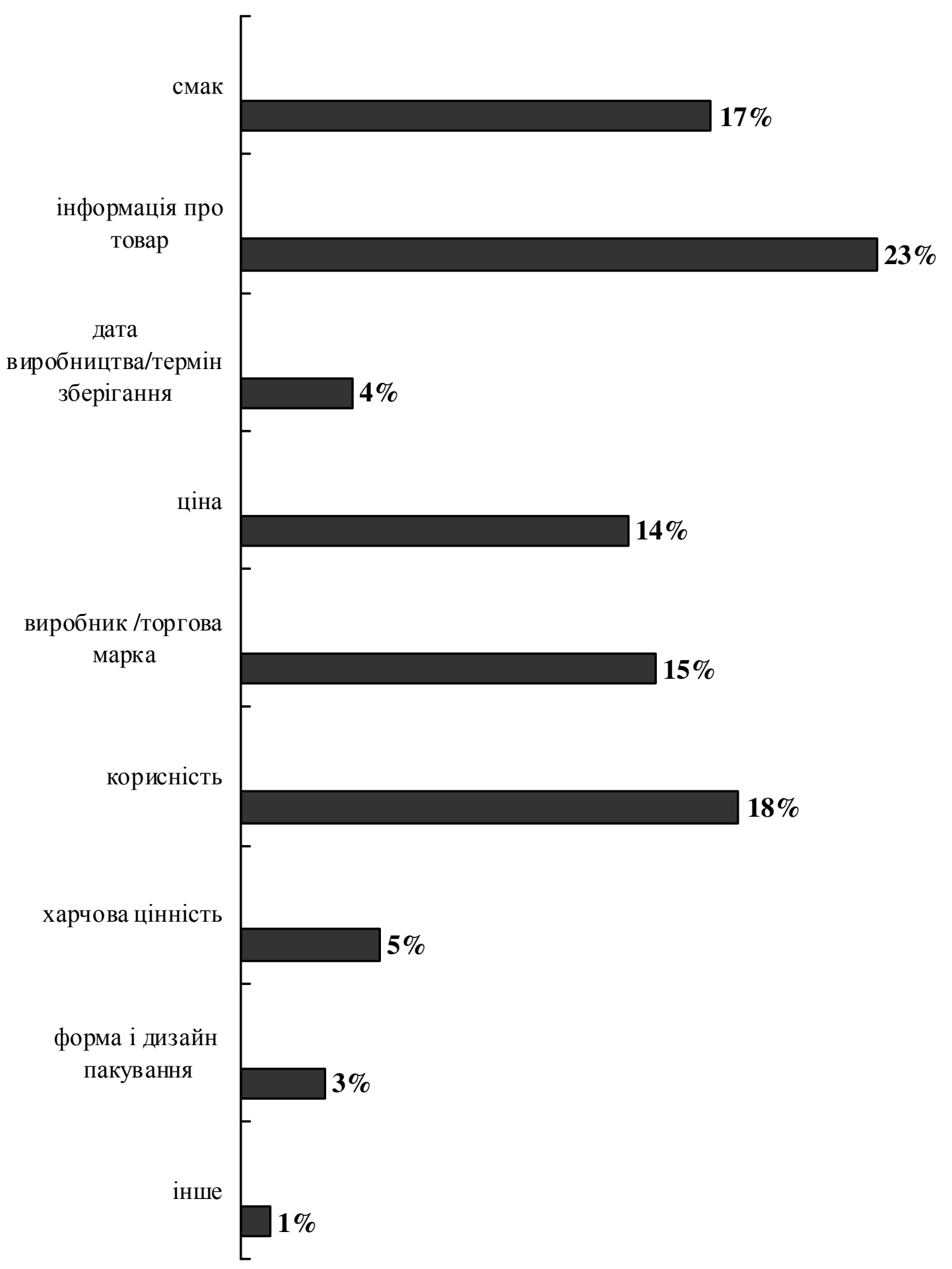

Рис. 1. Критерії вибору функціональних продуктів харчування 


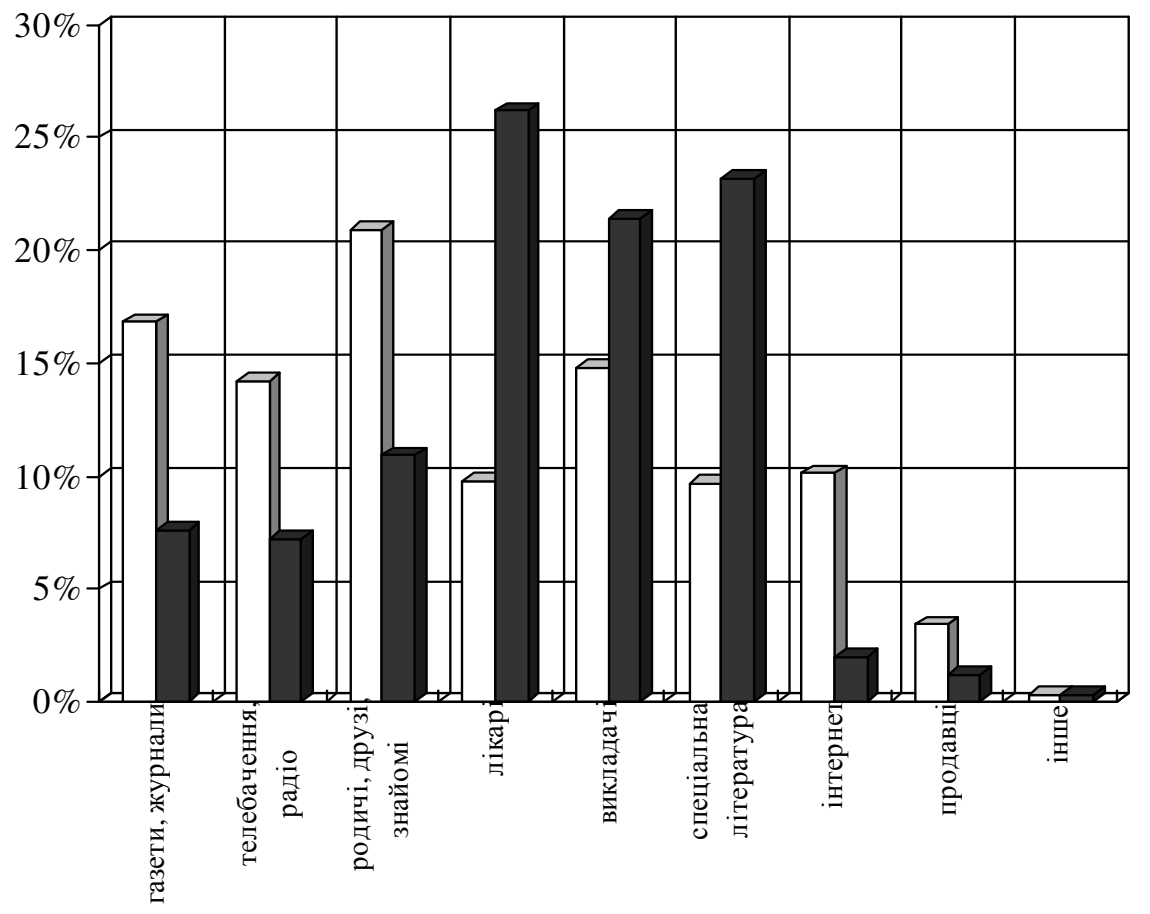

- джерела інформації; $\square$ - джерела інформації, котрим довіряють

Рис. 2. Найбільш популярні джерела інформації про здорове харчування, про функціональні продукти харчування

Низький рівень споживання ФПХ в Україні, на нашу думку, пояснюється низькою зацікавленістю споживачів у даній групі продуктів. Це обумовлено недостатньою інформацією та відсутністю знань у споживача про ФПХ. При цьому необхідно зазначити, що в умовах відсутності інформації (достатньої, доступної й достовірної споживчої інформації) про продукт, споживач не включає його в групу важливих потреб і не формує переваги до нього. Отримані цифри свідчать про необхідність додаткового інформування населення про здорове харчування, про ФПХ. Причому дана робота повинна лягти на плечі не тільки виробника (нанесення необхідної інформації на етикетку в доступній і зрозумілій формі), але й на систему освіти (наприклад, у деяких державах незалежно від отриманої спеціальності для тих, які навчаються, обов'язково вводять предмет про раціональне харчування й/або культуру харчування), а також державу (шляхом надання податкових та інших пільг на виготовлення й розміщення спеціальної реклами в 3MI).

На запитання: «Які рекламні засоби, на Ваш погляд, можливо для цього використовувати?» більшість респондентів (переважно люди старшого віку і 3 вищою освітою) віддали перевагу інформаційним статтям у журналах, газетах, спеціальній літературі. Молодь бажала б одержувати інформацію про дану проблему в першу чергу з інтернету, телебачення й радіо.
Порівняльний аналіз отриманих даних показує, що найбільш ефективними каналами поширення інформації про принципи здорового харчування, про ФПХ є: консультації медпрацівників; науковопопулярна й просвітницька робота фахівців у даній галузі (викладачів ВУЗів, співробітників науководослідних інститутів, що займаються питаннями харчування); публікації в газетах і журналах, спеціальній літературі, авторами яких є висококваліфіковані фахівці в галузі харчування й здоров'я [2].

До перспективних джерел інформації можна віднести: різні форми адресної реклами; лекції, проведені в організованих колективах по місцях навчання і роботи; інтернет, тому що більшу частину його користувачів становлять молоді люди, для яких профілактика 3 використанням ФПХ $є$ найбільш ефективною та доступною.

Враховуючи необхідність заповнення знань, які є основою для формування споживчих переваг до ФПХ, а також пріоритетність їх розробки й виробництва для забезпечення населення здоровим харчуванням, виконання цих завдань повинно починатися 3 просвітницької роботи серед населення в області здорового харчування в цілому й значення ФПХ для сучасної людини зокрема 


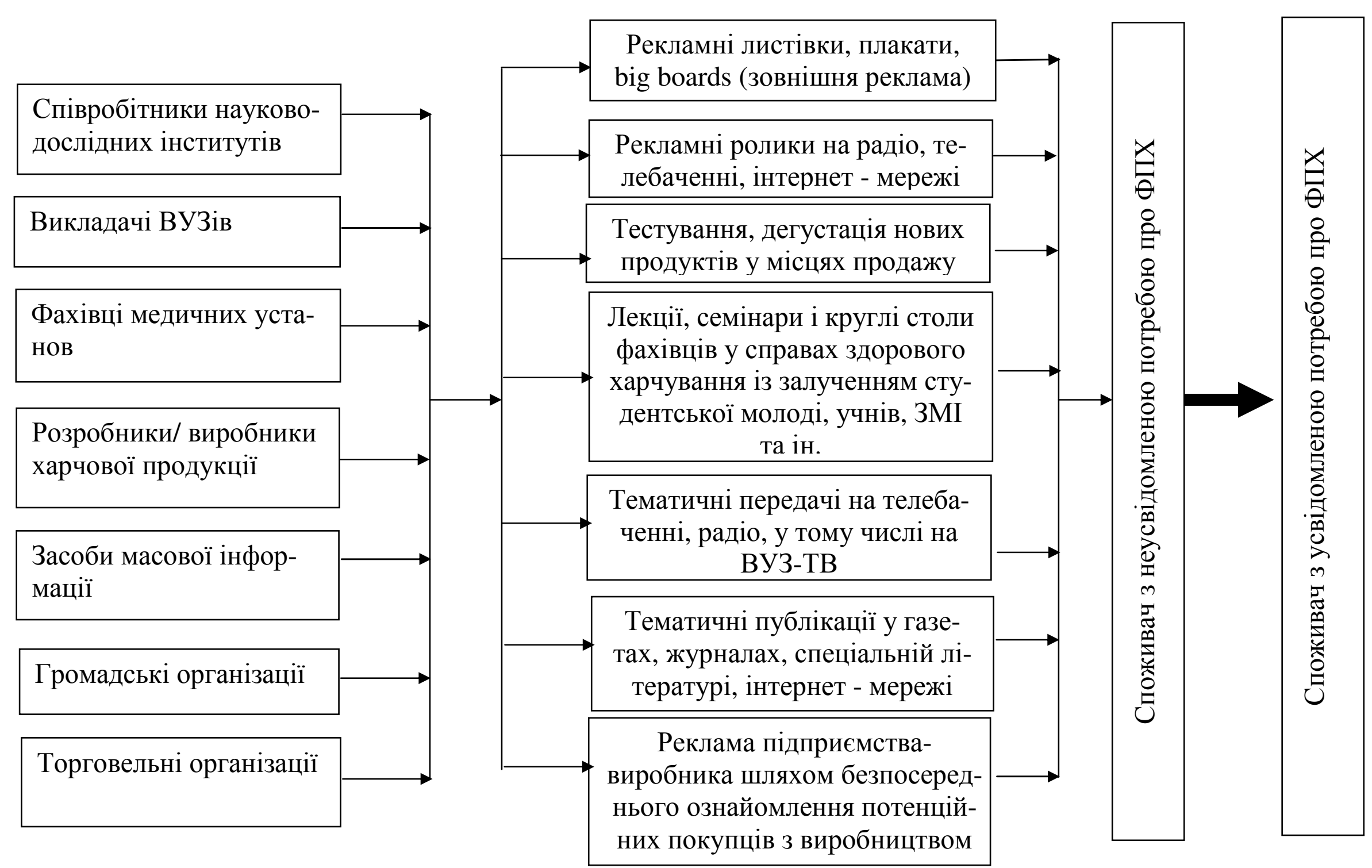

Рис. 3. Формування споживчих переваг до функціональних продуктів харчування 
Для рішення даної проблеми потрібно використовувати комплексний підхід, що охоплює роботу фахівців освітніх, медичних установ, розробників і виробників харчової продукції, засобів масової інформації та адміністрації різного рівня шляхом проведення семінарів, круглих столів, участі у тематичних телепередачах, освітніх програмах, публікаціях у газетах і журналах, спеціальній літературі, інтернетмережі та ін.

Нами в узагальненому вигляді запропоновані можливі рекламні засоби та дії, які повинні бути здійснені для формування споживчих переваг споживачів до ФПХ (рис. 3). Інформація, яка буде надходити за допомогою запропонованих дій до потенційного споживача про нові продовольчі товари, дозволить сформувати знання у споживача й тим самим забезпечити його усвідомлену потребу до нових продуктів, тобто мати на ринку сформовані споживчі переваги.

Висновки та перспективи подальших досліджень. Таким чином, формування знань у середовищі споживачів у питаннях харчування, здорового способу життя може привести до змін у культурі споживання, допоможе йому грамотно сформулювати свої вимоги й побажання, тим самим вплинути на споживчий попит на продукти функціонального харчування. 3 іншої сторони, на основі отриманих знань про споживчі переваги виробник зможе випускати високоякісну конкурентоспроможну продукцію 3 поліпшеними споживними властивостями.

\title{
Література
}

1. Пилат Т. Л. Биологически активные добавки к пище (теория, производство, применение) [Текст] / Т. Л. Пилат, А. А. Иванов. - М. : Авалон, 2002. - 710 с.

2. Єгоров Б. В. Наукові основи формування споживних властивостей нових зернових продуктів : Монографія [Текст] / Б. В. Сгоров, М. Р. Мардар - Одеса : ТЕС, 2013. - 388 с.

3. Цимбалиста Н. В. Стан фактичного харчування населення та аліментарно обумовлена захворюваність [Текст] / Н. В. Цимбалиста, Н. В. Давиденко // Пробл. харчування. - 2008. - №1-2. - С. 32-35.

4. Банковська Н. В. Гігієнічна оцінка стану фактичного харчування дорослого населення України та наукове обгрунтування шляхів його оптимізації. [Текст] : автореф. дис. ... канд. мед. наук : 14.02 .01 / Банковська Наталія Володимирівна; Нац. мед. ун-т ім. О. О. Богомольця. - К., 2008. - 26 с.

5. Roberfroid M. B. Global view on functional foods: European perspectives [Text] / M. B. Roberfroid // Brit. J. Nutr. - 2002. - Vol. 88, № 2. - P.133-138.

6. Diplock A.T. Scientific concepts of functional foods in Europe: consensus document [Text] / A. T. Diplock, P. J. Agget, M. Ashwell // Brit. J. Nutr.- 1999. - Vol. 81, № 1. - P. 1-7.

7. Knorr D. Functional food science and Technology. [Text] / D. Knorr. - 1998. - Vol. 9. - P. 295-340.

8. Milner J. A. Functional foods and health: a US perspective. [Text] / J. A. Milner // Brit. J. Nutr. - 2002. Vol. 88, № 2. - P. 151-158.

9. Erbersdobler H. F. Summarising lecture and prospects for future research and development [Text] / H. F. Erbersdobler // Food Research Intern. - 2002. - Vol. 35. - P. 323-325.

10. Weststrate, J.A. Functional Foods, trends and future [Text] / J.A. Weststrate, G.V.Poppel, P.M. Verschuren // Brit. J. Nutr. - 2002. - Vol. 88, № 2. - P. 233-235.

11. Державний комітет статистики України [Електронний ресурс]: офіц. сайт. - Режим доступу : http://www.ukrstat.gov.ua. - Назва з екрана.

12. Маюрникова Л. А. Формирование потребительских предпочтений к новационным продуктам питания в региональных условиях [Текст] / Л. А. Маюрникова, С. В. Новоселов, Е. Н. Болховитина // Ползуновский вестник. - 2010. - № 4/2. - С. 13-19.

\author{
Мардар М.P. \\ доктор технических наук, доцент \\ профессор кафедры маркетинга, предпринимательства и торговли \\ Одесская национальная академия пищевых технологий \\ ул. Канатная, 112, г. Одесса, Украина, 65039 \\ E-mail: marina_mardar@mail.ru
}

\section{ФОРМИРОВАНИЕ ПОТРЕБИТЕЛЬСКИХ ПРЕДПОЧТЕНИЙ К ФУНКЦИОНАЛЬНЫМ ПРОДУКТАМ ПИТАНИЯ НА ОСНОВЕ МАРКЕТИНГОВЫХ ИССЛЕДОВАНИЙ}

\footnotetext{
Представлены результаты маркетинговых исследований отношения потребителей к функциональным продуктам питания, выявлено каким уровнем знаний обладает потенциальный потребитель и на основе полученных результатов предложены пути фрормирования потребительских предпочтений к фрункциональным
} 
продуктам питания. Информация, которая будет поступать с помощью предложенных мероприятий, позволит сфрормировать знания в среде потребителей и тем самым обеспечить его осознанную потребность к новым продуктам, то есть иметь на рынке сформированные потребительские предпочтения.

Ключевые слова: маркетинговые исследования, потребитель, функциональные продукты питания, потребительские предпочтения.

\section{Mardar M.R.}

Doctor of Techn. Sciences, Associate Professor

Professor of Marketing, Business and Trade Department

Odessa National Academy of Food Technologies

Kanatnaya Str., 112, Odessa, Ukraine, 65039

E-mail:marina_mardar@mail.ru

\section{FORMATION OF CONSUMER PREFERENCES FOR FUNCTIONAL FOOD ON THE BASIS OF MARKETING RESEARCHES}

Results of market researches of the relation of consumers to functional food are presented, is revealed by what level of knowledge the potential consumer possesses and on the basis of the received results ways of formation of consumer preferences to functional food are offered. Information which will arrive by means of the offered actions will allow to create knowledge among consumers and by that to provide his conscious requirement to new products, that is to have the created consumer preferences in the market.

Making the decision on purchase of the goods created taking into account all actions, the consumer gets foodstuff with the improved consumer properties. As a result the human body is revitalized and it has satisfaction from the acquired goods. As a result win all parties: the developer achieves introduction of the ideas in production, the producer realizes goods and gets profit and, most important, the consumer acquires not simply goods, and a useful product.

Keywords: market researches, consumer, functional food, consumer preferences.

\section{References}

1. Pylat T. L. (2002). Byolohychesky aktyvnye dobavky k pyshche (teoryya, proyzvodstvo, prymenenye) [Tekst] . T. L. Pylat, A. A. Yvanov. M.: Avalon, 710.

2. Yehorov B. V. (2013). Naukovi osnovy formuvannya spozhyvnykh vlastyvostey novykh zernovykh produktiv: Monohrafiya [Tekst]. B. V. Yehorov, M. R. Mardar. Odesa: TES, 388 .

3. Tsymbalysta N. V. (2008). Stan faktychnoho kharchuvannya naselennya ta alimentarno obumovlena zakhvoryuvanist' [Tekst]. N. V. Tsymbalysta, N.V. Davydenko. Probl. kharchuvannya, 1-2, 32-35.

4. Bankovs'ka N.V. (2008). Hihiyenichna otsinka stanu faktychnoho kharchuvannya dorosloho naselennya Ukrayiny ta naukove obgruntuvannya shlyakhiv yoho optymizatsiyi. [Tekst]: avtoref. dys. ... kand. med. nauk: 14.02.01. Bankovs'ka Nataliya Volodymyrivna; Nats. med. un-t im. O.O. Bohomol'tsya. K., 26.

5. Roberfroid M. B. Global view on functional foods: European perspectives [Text]. M. B. Roberfroid. Brit. J. Nutr. 2002. Vol. 88, № 2. P. 133-138.

6. Diplock A. T. Scientific concepts of functional foods in Europe: consensus document [Text]. A. T. Diplock, P. J. Agget, M. Ashwell. Brit. J. Nutr. 1999. Vol. 81, № 1. P. 1-7.

7. Knorr D. Functional food science and Technology. [Text]. D. Knorr. 1998. Vol. 9. P. 295-340.

8. Milner J. A. Functional foods and health: a US perspective [Text]. J. A. Milner. Brit. J. Nutr. 2002. Vol. 88, № 2. P. 151-158.

9. Erbersdobler H. F. Summarising lecture and prospects for future research and development [Text]. H. F. Erbersdobler. Food Research Intern. 2002. Vol. 35. P. 323-325.

10. Weststrate J. A. Functional Foods, trends and future [Text]. J. A. Weststrate, G. V. Poppel, P. M. Verschuren. Brit. J. Nutr. 2002. Vol. 88, № 2. P. 233-235.

11. Derzhavnyy komitet statystyky Ukrayiny [Elektronnyy resurs]: ofits. sayt. - Rezhym dostupu: http : //www.ukrstat.gov.ua. Nazva z ekrana.

12. Mayurnykova L. A. (2010). Formyrovanye potrebytel'skykh predpochtenyy k novatsyonnym produktam pytanyya $\mathrm{v}$ rehyonal'nykh uslovyyakh [Tekst]. L. A. Mayurnykova, S. V. Novoselov, E. N. Bolkhovytyna. Polzunovskyy vestnyk. 4/2, 13-19. 